\title{
Efficacy of florfenicol and intravenous fluid therapy for treatment of experimental salmonellosis in newborn calves
}

\author{
[Eficácia do florfenicol e da fluidoterapia parenteral no tratamento \\ da salmonelose experimental em bezerros neonatos] \\ D.G. Silva ${ }^{1}$, P.R.L. Silva ${ }^{1}$, J.J. Fagliari ${ }^{2 *}$ \\ ${ }^{1}$ Aluna de pós-graduação - DCCV-FCAV-UNESP - Jaboticabal, SP \\ ${ }^{2}$ Médico veterinário autônomo \\ ${ }^{3}$ Faculdade de Ciências Agrárias e Veterinária - UNESP \\ Via de Acesso Prof. Paulo Donato Castellane, s/n \\ 14884-900 - Jaboticabal, SP
}

\begin{abstract}
The efficacy of florfenicol associated or not to intravenous fluid therapy for treatment of Salmonella Dublin-infected calves was determined. Twenty-four healthy 10 to 15 -day-old Holstein calves were randomly allotted into four groups, with six animals each: control (group 1); infected with $10^{8} \mathrm{CFU}$ Salmonella Dublin and not treated (group 2); infected with $10^{8} \mathrm{CFU}$ Salmonella Dublin and treated with florfenicol (group 3); and infected with $10^{8} \mathrm{CFU}$ Salmonella Dublin and treated with florfenicol associated to fluid therapy (group 4). All animals were submitted to physical examination just before inoculation and every 24 hours, during seven days after experimental infection. Rectal swabs and blood samples were collected for Salmonella Dublin isolation and $\mathrm{pH}$ and blood electrolytes determination. The experimental infection with Salmonella Dublin induced clinical signs of salmonellosis, such as diarrhea and fever, and caused reduction in blood concentrations of $\mathrm{pH}$, sodium, potassium and chlorides. The treated calves showed good clinical recovery, and the group treated with antibiotic in combination to fluid therapy presented a faster and more efficient correction of the hydro-electrolyte balance.
\end{abstract}

Keywords: calf, Salmonella Dublin, florfenicol, lactated Ringer's solution

\section{RESUMO}

Avaliou-se a eficácia terapêutica do florfenicol associado ou não à fluidoterapia intravenosa no tratamento de bezerros infectados experimentalmente com Salmonella Dublin. Foram utilizados 24 bezerros sadios da raça Holandesa com 10 a 15 dias de idade, distribuídos aleatoriamente em quatro grupos experimentais, constituídos por seis animais cada: controle (grupo 1); infectado com $10^{8}$ UFC de Salmonella Dublin e não tratado (grupo 2); infectado com $10^{8} U F C$ de Salmonella Dublin e tratado com florfenicol (grupo 3); $e$ infectado com $10^{8}$ UFC de Salmonella Dublin (grupo 4) e tratado com florfenicol associado à fluidoterapia. Todos os animais foram submetidos ao exame físico logo antes da inoculação e a cada 24 horas, durante sete dias após a infecção experimental. Foram colhidas amostras de suabes retais para o isolamento de Salmonella Dublin e amostras de sangue para determinação dos valores de $\mathrm{pH}$ e dosagem de eletrólitos sanguíneos. A infecção experimental com Salmonella Dublin induziu sinais clínicos de salmonelose, como diarreia e febre, $e$ provocou redução do valor do pH e das concentrações sanguíneas de sódio, potássio e cloreto. Os bezerros submetidos aos tratamentos mostraram boa recuperação clínica, sendo que o grupo tratado com antibiótico combinado à fluidoterapia apresentou correção mais rápida e eficiente do equilíbrio hidroeletrolítico.

Palavras-chave: bezerro, Salmonella Dublin, florfenicol, Ringer com lactato de sódio

Recebido em 21 de outubro de 2009

Aceito em 10 de maio de 2010

*Autor para correspondência (corresponding author)

E-mail: fagliari@fcav.unesp.br 


\section{INTRODUCTION}

Bovine salmonellosis is a disease of great relevance due to its occurrence, economical importance, and implications in public health (Santos et al., 2002; Veling et al., 2002). The serovars Salmonella Dublin and Salmonella Typhimurium are the most isolated in cattle herds, and $S$. Dublin is the main cattle-adapted serovar (Smith et al., 1989; Pereira et al., 2004; Silva et al., 2008a).

The most common clinical signs reported in newborn calves with salmonellosis include dehydration, diarrhea, and metabolic acidosis (Fecteau et al., 2003; Silva et al., 2008b). Thus, practical and economical treatments for the control of the bacteremia, rehydration, and correction of electrolyte and acid-base imbalance are fundamental for the reduction of the incidence, mortality, and losses associated to this disease (House and Smith, 1998).

The aim of this study was to determine the efficacy of florfenicol associated or not to parenteral fluid therapy for treatment of Salmonella Dublin-infected calves.

\section{MATERIAL AND METHODS}

Twenty-four 10 to 15-day-old Holstein calves averaging $41 \mathrm{~kg}$ body weight were evaluated and equally distributed into four groups: control (group 1); orally infected with $10^{8} \mathrm{CFU}$ Salmonella Dublin and not treated (group 2); orally infected with $10^{8} \mathrm{CFU}$ Salmonella Dublin and treated with $20 \mathrm{mg}$ of florfenicol $/ \mathrm{kg}$ at the onset of the clinical signs of infection, in two doses via IM, every 48 hours (group 3); and orally infected with $10^{8} \mathrm{CFU}$ Salmonella Dublin and treated with $20 \mathrm{mg}$ of florfenicol $/ \mathrm{kg}$ at the onset of the clinical signs, in two IM doses, every 48 hours, associated with intravenous fluid therapy with lactated Ringer's solution at dose of $60 \mathrm{~mL} / \mathrm{kg} /$ day (group 4). During the experimental period, the calves were housed in individual stalls and received four liters of pasteurized milk, twice a day, and also were fed ration and water ad libitum. The Institutional Ethics and Animal Welfare Commission from the FCAV/UNESP/Campus de Jaboticabal approved this study.
The inoculum used in the experimental infection was prepared from Salmonella Dublin sample (register IOC 3101/03), naturally resistant to nalidixic acid, donated by Fundação Oswaldo Cruz (Manguinhos, RJ).

Blood samples and rectal swabs were collected minutes before the inoculation ( 0 hour) and also 24, 48, 72, 96, 120, 144, and 168 hours after experimental infection.

Blood samples were taken from the jugular vein using a $25 \times 7 \mathrm{~mm}$ needle attached to a $1 \mathrm{~mL}$ syringe containing sodium heparin, according to the recommendations of Lisbôa et al. (2001), for determining values of $\mathrm{pH}$, and concentrations of sodium, potassium, and chloride using an automatic analyzer (Omni C, Roche - São Paulo, Brazil ).

The calves were submitted to a daily physical evaluation (Dirksen et al., 1993), and body weight was measured at the beginning and at the end of the study.

The detection of Salmonella Dublin in fecal samples was made by incubation of rectal swabs in two selective enrichment broth (selenite cystine and Muller-Kauffmann tetrathionate), followed by transfer into a semi-solid medium

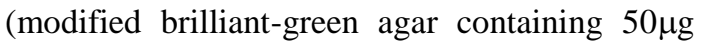
nalidixic acid/mL), biochemical tests (triplice sugar iron agar and lysine-iron agar), and serological confirmation (Salmonella polyvalent somatic and flagellar antisera).

Repeated measures analysis of variance was the statistical method used to evaluate the parametric responses. Pairwise comparisons of means were made using Tukey's procedure. A P value $<0.05$ was considered significant. The fecal consistency scores were analyzed using non-parametric Kruskal-Wallis test and pairwise comparisons of means were made using Dunn's test. A P value $<0.05$ was considered significant (ZAR, 1999).

\section{RESULTS AND DISCUSSION}

Before inoculation with Salmonella Dublin, the clinical parameters of the evaluated groups were within the normal range for cattle (Dirksen et al., 1993). Twenty-four to 48 hours after the experimental infection with Salmonella Dublin, all calves from groups 2,3 , and 4 presented a 
mild to severe diarrhea, with detection of the bacterium in at least one of the selective enrichment broths (Table 1 and Figure 1a). In the animals from groups 3 and 4 it was observed that the feces consistency improved immediately after the beginning of antibiotic therapy, with or without simultaneous fluid therapy, and most of the animals no longer shed the bacteria in feces (Table 1 and Figure 2a).

Table 1 . Mean $( \pm \mathrm{SD})$ of fecal consistency scores $(0=$ normal; $1=$ mild diarrhea; $2=$ severe to moderate diarrhea); rectal temperature $\left({ }^{\circ} \mathrm{C}\right) ; \mathrm{pH}$, sodium $(\mathrm{mMol} / \mathrm{L})$, potassium $(\mathrm{mMol} / \mathrm{L})$, and chloride concentrations $(\mathrm{mMol} / \mathrm{L})$ in calves from control group (group 1); calves experimentally infected with $10^{8} \mathrm{CFU}$ Salmonella Dublin (group 2); calves infected and treated with florfenicol (group 3); and calves infected and treated with florfenicol and fluid therapy (group 4), before inoculation (0 hour) and 24, 48, $72,96,120,144$, and 168 hours after experimental infection

\begin{tabular}{|c|c|c|c|c|c|c|c|c|}
\hline \multicolumn{4}{|c|}{ Variables } & \multicolumn{5}{|c|}{ Ime after Salmonella Dublin inoculation (hours) } \\
\hline & 0 & 24 & 48 & 72 & 96 & 120 & 144 & 168 \\
\hline \multicolumn{9}{|c|}{ Fecal consistency scores* } \\
\hline G1 & $0.00 \pm 0.00 \mathrm{Aa}$ & $0.00 \pm 0.00 \mathrm{Aa}$ & $0.00 \pm 0.00 \mathrm{Aa}$ & $0.00 \pm 0.00 \mathrm{Aa}$ & $0.00 \pm 0.00 \mathrm{Aa}$ & $0.00 \pm 0.00 \mathrm{Aa}$ & $0.00 \pm 0.00 \mathrm{Aa}$ & $0.00 \pm 0.00 \mathrm{Aa}$ \\
\hline G2 & $0.00 \pm 0.00 \mathrm{Aa}$ & $0.80 \pm 0.80 \mathrm{ABa}$ & $1.20 \pm 0.80 \mathrm{ABa}$ & $1.30 \pm 0.50 \mathrm{Ba}$ & $1.40 \pm 0.50 \mathrm{Ba}$ & $1.40 \pm 0.50 \mathrm{Ba}$ & $1.40 \pm 0.50 \mathrm{Ba}$ & $1.00 \pm 1.20 \mathrm{Aa}$ \\
\hline G3 & $0.00 \pm 0.00 \mathrm{Aa}$ & $1.80 \pm 0.40 \mathrm{Bb}$ & $1.70 \pm 0.50 \mathrm{Bb}$ & $1.30 \pm 0.50 \mathrm{Bab}$ & $1.00 \pm 0.00 \mathrm{ABab}$ & $0.30 \pm 0.80 \mathrm{ABab}$ & $0.30 \pm 0.50 \mathrm{ABab}$ & $\begin{array}{c}0.70 \pm 0.50 \mathrm{Aa} \\
\mathrm{b}\end{array}$ \\
\hline G4 & $0.00 \pm 0.00 \mathrm{Aa}$ & $1.50 \pm 0.50 \mathrm{Ba}$ & $1.50 \pm 0.50 \mathrm{Ba}$ & $1.20 \pm 0.80 \mathrm{ABa}$ & $1.00 \pm 0.60 \mathrm{ABa}$ & $0.80 \pm 0.80 \mathrm{ABa}$ & $0.70 \pm 0.50 \mathrm{ABa}$ & $0.50 \pm 0.50 \mathrm{Aa}$ \\
\hline \multicolumn{9}{|c|}{ Rectal temperature $\left({ }^{\circ} \mathrm{C}\right)$} \\
\hline G1 & $38.5 \pm 0.50 \mathrm{Aa}$ & $38.6 \pm 0.29 \mathrm{Aa}$ & $38.3 \pm 0.22 \mathrm{Aa}$ & $38.3 \pm 0.29 \mathrm{Aa}$ & $38.3 \pm 0.46 \mathrm{Aa}$ & $38.4 \pm 0.31 \mathrm{Aa}$ & $38.4 \pm 0.42 \mathrm{Aa}$ & $38.4 \pm 0.48 \mathrm{Aa}$ \\
\hline G2 & $38.9 \pm 0.50 \mathrm{Aa}$ & $39.0 \pm 0.16 \mathrm{Aa}$ & $39.0 \pm 0.52 \mathrm{ABa}$ & $39.4 \pm 0.79 \mathrm{Aa}$ & $39.9 \pm 0.75 \mathrm{Ba}$ & $39.7 \pm 0.77 \mathrm{Ba}$ & $39.4 \pm 2.03 \mathrm{Aa}$ & $40.4 \pm 0.97 \mathrm{Bb}$ \\
\hline G3 & $39.1 \pm 0.65 \mathrm{Aa}$ & $39.3 \pm 0.58 \mathrm{Aa}$ & $39.5 \pm 0.75 \mathrm{Ba}$ & $39.1 \pm 0.63 \mathrm{Aa}$ & $38.7 \pm 0.41 \mathrm{Aa}$ & $38.6 \pm 0.15 \mathrm{ABa}$ & $38.6 \pm 0.17 \mathrm{Aa}$ & $38.5 \pm 0.21 \mathrm{Aa}$ \\
\hline G4 & $38.8 \pm 0.63 \mathrm{Aa}$ & $38.9 \pm 0.38 \mathrm{Aa}$ & $39.2 \pm 0.64 \mathrm{ABa}$ & $38.6 \pm 0.20 \mathrm{Aa}$ & $38.8 \pm 0.34 \mathrm{ABa}$ & $38.5 \pm 0.21 \mathrm{Aa}$ & $38.6 \pm 0.50 \mathrm{Aa}$ & $38.7 \pm 0.42 \mathrm{Aa}$ \\
\hline \multicolumn{9}{|l|}{ pH } \\
\hline G1 & $7.35 \pm 0.03 \mathrm{Aa}$ & $7.34 \pm 0.03 \mathrm{Aa}$ & $7.34 \pm 0.01 \mathrm{Aa}$ & $7.34 \pm 0.01 \mathrm{Aa}$ & $7.36 \pm 0.04 \mathrm{Aa}$ & $7.36 \pm 0.02 \mathrm{Aa}$ & $7.37 \pm 0.02 \mathrm{Aa}$ & $7.38 \pm 0.03 \mathrm{Aa}$ \\
\hline G2 & $7.33 \pm 0.05 \mathrm{Aa}$ & $7.35 \pm 0.05 \mathrm{Aa}$ & $7.36 \pm 0.02 \mathrm{Aa}$ & $7.32 \pm 0.07 \mathrm{Aa}$ & $7.32 \pm 0.11 \mathrm{Aa}$ & $7.31 \pm 0.11 \mathrm{Aa}$ & $7.28 \pm 0.16 \mathrm{Aa}$ & $7.35 \pm 0.03 \mathrm{Aa}$ \\
\hline G3 & $7.31 \pm 0.05 \mathrm{Aa}$ & $7.30 \pm 0.05 \mathrm{Aa}$ & $7.29 \pm 0.06 \mathrm{Aa}$ & $7.31 \pm 0.03 \mathrm{Aa}$ & $7.31 \pm 0.04 \mathrm{Aa}$ & $7.33 \pm 0.02 \mathrm{Aa}$ & $7.32 \pm 0.04 \mathrm{Aa}$ & $7.35 \pm 0.02 \mathrm{Aa}$ \\
\hline G4 & $7.31 \pm 0.03 \mathrm{Aa}$ & $7.30 \pm 0.11 \mathrm{Aa}$ & $7.29 \pm 0.10 \mathrm{Aa}$ & $7.33 \pm 0.07 \mathrm{Aa}$ & $7.35 \pm 0.04 \mathrm{Aa}$ & $7.36 \pm 0.02 \mathrm{Aa}$ & $7.36 \pm 0.02 \mathrm{Aa}$ & $7.35 \pm 0.04 \mathrm{Aa}$ \\
\hline \multicolumn{9}{|c|}{$\mathrm{Na}(\mathrm{mMol} / \mathrm{L})$} \\
\hline G1 & $143 \pm 2.05 \mathrm{Aa}$ & $143 \pm 1.22 \mathrm{Aa}$ & $142 \pm 1.46 \mathrm{Aa}$ & $141 \pm 0.70 \mathrm{Aa}$ & $143 \pm 1.89$ Aa & $143 \pm 1.23 \mathrm{Aa}$ & $143 \pm 0.67 \mathrm{Aa}$ & $143 \pm 1.33 \mathrm{Aa}$ \\
\hline G2 & $142 \pm 3.26 \mathrm{Aa}$ & $141 \pm 2.23$ Aa & $140 \pm 2.24 \mathrm{Aa}$ & $140 \pm 3.63$ Aa & $140 \pm 4.62 \mathrm{Aa}$ & $138 \pm 5.03 \mathrm{Ba}$ & $139 \pm 5.55 \mathrm{Aa}$ & $141 \pm 2.92 \mathrm{Aa}$ \\
\hline G3 & $139 \pm 4.16 \mathrm{Aa}$ & $139 \pm 4.97 \mathrm{Aa}$ & $140 \pm 5.84 \mathrm{Aa}$ & $140 \pm 5.00 \mathrm{Aa}$ & $141 \pm 4.42 \mathrm{Aa}$ & $141 \pm 4.00 \mathrm{ABa}$ & $141 \pm 5.50 \mathrm{Aa}$ & $142 \pm 2.64 \mathrm{Aa}$ \\
\hline G4 & $141 \pm 3.35 \mathrm{Aa}$ & $142 \pm 4.18 \mathrm{Aa}$ & $142 \pm 5.06 \mathrm{Aa}$ & $142 \pm 4.04 \mathrm{Aa}$ & $143 \pm 1.98 \mathrm{Aa}$ & $142 \pm 2.34 \mathrm{ABa}$ & $142 \pm 2.46$ Aa & $143 \pm 1.65 \mathrm{Aa}$ \\
\hline \multicolumn{9}{|c|}{ K $(\mathbf{m M o l} / \mathbf{L})$} \\
\hline G1 & $4.11 \pm 0.35 \mathrm{Aa}$ & $3.98 \pm 0.36 \mathrm{Aa}$ & $4.01 \pm 0.39 \mathrm{Aa}$ & $3.97 \pm 0.19 \mathrm{Aa}$ & $3.82 \pm 0.18 \mathrm{Aa}$ & $3.87 \pm 0.19 \mathrm{Aa}$ & $3.96 \pm 0.31 \mathrm{Aa}$ & $4.00 \pm 0.22 \mathrm{Aa}$ \\
\hline G2 & $3.76 \pm 0.15 \mathrm{Aa}$ & $3.75 \pm 0.15 \mathrm{Aa}$ & $3.76 \pm 0.05 \mathrm{Aa}$ & $3.65 \pm 0.21 \mathrm{Aa}$ & $3.57 \pm 0.16 \mathrm{Aa}$ & $3.68 \pm 0.18 \mathrm{Aa}$ & $3.78 \pm 0.12 \mathrm{Aa}$ & $3.94 \pm 0.27 \mathrm{Aa}$ \\
\hline G3 & $3.98 \pm 0.24 \mathrm{Aa}$ & $3.80 \pm 0.12 \mathrm{Aa}$ & $3.99 \pm 0.23 \mathrm{Aa}$ & $4.04 \pm 0.27 \mathrm{Aa}$ & $3.97 \pm 0.31 \mathrm{Aa}$ & $3.83 \pm 0.17 \mathrm{Aa}$ & $4.18 \pm 0.41 \mathrm{Aa}$ & $4.00 \pm 0.26 \mathrm{Aa}$ \\
\hline G4 & $3.99 \pm 0.21 \mathrm{Aa}$ & $4.03 \pm 0.78 \mathrm{Aa}$ & $3.79 \pm 0.31 \mathrm{Aa}$ & $3.78 \pm 0.24 \mathrm{Aa}$ & $3.63 \pm 0.21 \mathrm{Aa}$ & $3.95 \pm 0.34 \mathrm{Aa}$ & $3.81 \pm 0.24 \mathrm{Aa}$ & $3.72 \pm 0.30 \mathrm{Aa}$ \\
\hline \multicolumn{9}{|c|}{$\mathrm{Cl}(\mathrm{mMol} / \mathrm{L})$} \\
\hline G1 & $107 \pm 0.80 \mathrm{Aa}$ & $105 \pm 1.52 \mathrm{Aa}$ & $104 \pm 1.12 \mathrm{Aa}$ & $103 \pm 0.60 \mathrm{Aa}$ & $105 \pm 2.09 \mathrm{Aa}$ & $104 \pm 0.83 \mathrm{Aa}$ & $103 \pm 1.17 \mathrm{Aa}$ & $105 \pm 0.93 \mathrm{Aa}$ \\
\hline G2 & $105 \pm 4.08 \mathrm{Aa}$ & $104 \pm 4.06 \mathrm{Aa}$ & $103 \pm 2.62 \mathrm{Aa}$ & $103 \pm 2.62 \mathrm{Aa}$ & $104 \pm 1.53 \mathrm{Aa}$ & $102 \pm 2.49 \mathrm{Aa}$ & $103 \pm 1.75 \mathrm{Aa}$ & $102 \pm 2.37 \mathrm{Aa}$ \\
\hline G3 & $104 \pm 2.56 \mathrm{Aa}$ & $103 \pm 2.66 \mathrm{Aa}$ & $103 \pm 3.76 \mathrm{Aa}$ & $105 \pm 4.31 \mathrm{Aa}$ & $104 \pm 4.09 \mathrm{Aa}$ & $106 \pm 4.17 \mathrm{Aa}$ & $103 \pm 6.20 \mathrm{Aa}$ & $104 \pm 4.17 \mathrm{Aa}$ \\
\hline G4 & $106 \pm 2.89 \mathrm{Aa}$ & $104 \pm 2.97 \mathrm{Aa}$ & $105 \pm 1.96 \mathrm{Aa}$ & $103 \pm 3.13 \mathrm{Aa}$ & $104 \pm 2.24 \mathrm{Aa}$ & $102 \pm 3.07 \mathrm{Aa}$ & $103 \pm 2.13 \mathrm{Aa}$ & $105 \pm 1.15 \mathrm{Aa}$ \\
\hline
\end{tabular}

Means followed by different capital letters in the same column and lower case letters in the same line differ statistically by Dunn's $(*)$ test or Tukey's test $(\mathrm{P}<0.05)$.

It was observed a gradual increase of the rectal temperature in calves from group 2 along the experimental period, while the groups that were inoculated and treated presented a short period of temperature increase (group 3) or did not present significant alterations in rectal temperature (group 4) (Table 1 and Figure 1b). In a similar way, Osborne et al. (1978) and Fecteau et al. (2003) verified that calves infected with Salmonella and treated with antibiotic presented less days of fever and diarrhea. The mean values of blood $\mathrm{pH}$ presented mild variations during the experimental period, except for animals from group 2 , whose $\mathrm{pH}$ values decreased markedly 48 hours after the inoculation, reaching the lowest value at 144 hours (Table 1 and Figure 1c). According to Naylor (1987) and Leal et al. (2007), one of the main biochemical alterations in animals with diarrhea is metabolic acidosis, characterized by decrease of the blood $\mathrm{pH}$, due to fecal loss of bicarbonate. In groups 3 and 4 there was an increase of the $\mathrm{pH}$, which was higher in calves that received fluid therapy (group 4). There were also reduction in sodium, potassium, and chloride concentrations 24 hours after the experimental infection in animals from groups 2 , 3, and 4, due to fecal losses (Gonçalves et al., 1991), and increase in the concentration of these electrolytes in animals from groups 3 and 4 after the beginning of the treatment (Table 1 and Figure 1d to 1f). 

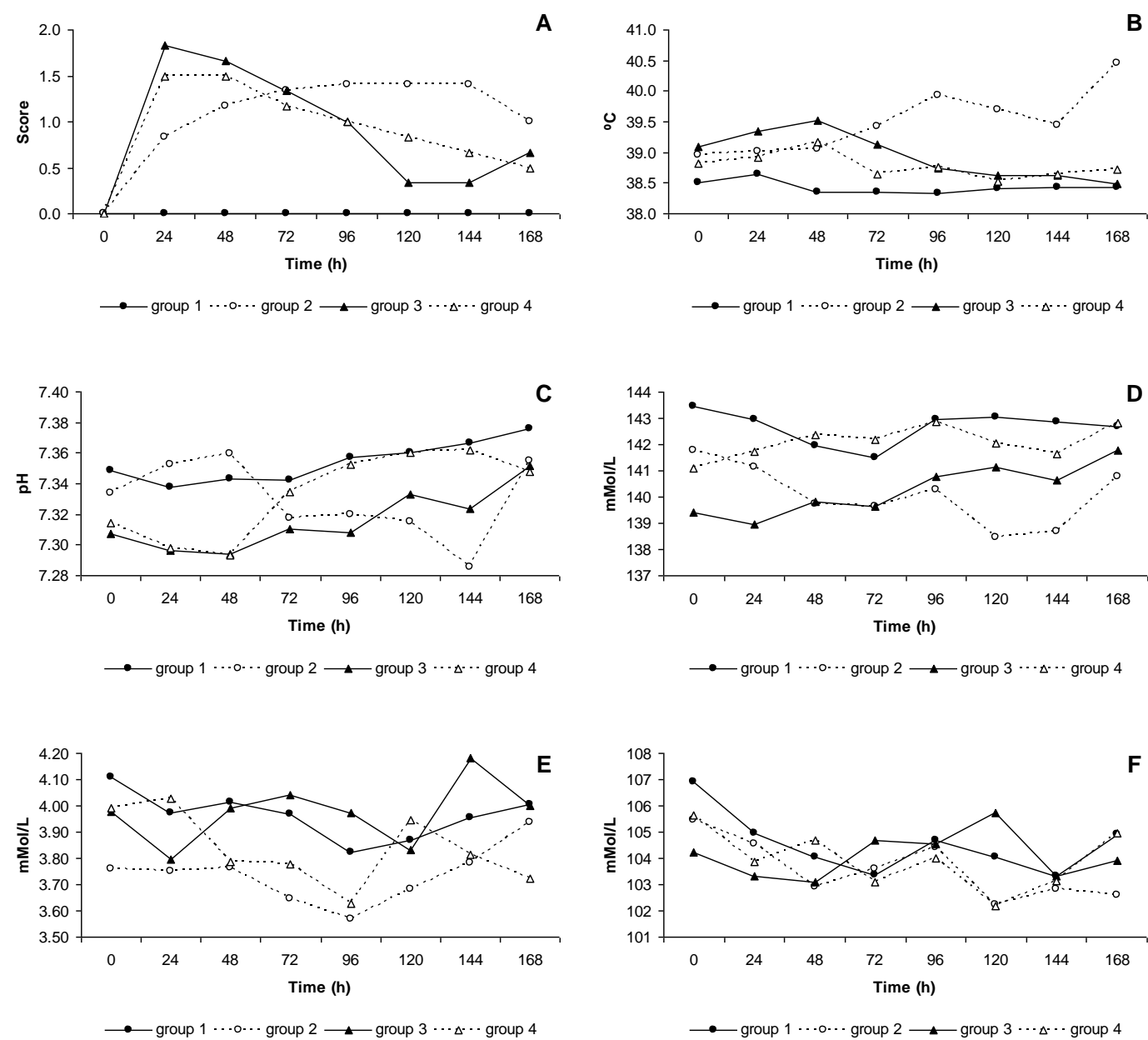

Figure 1. A: fecal consistency scores $(0=$ normal; $1=$ mild diarrhea; $2=$ severe to moderate diarrhea $)$; $\mathbf{B}$ : rectal temperature $\left({ }^{\circ} \mathrm{C}\right)$; $\mathbf{C}$ : blood $\mathrm{pH} ; \mathbf{D}$ : sodium $(\mathrm{mMol} / \mathrm{L}) ; \mathbf{E}$ : potassium $(\mathrm{mMol} / \mathrm{L}) ; \mathbf{F}$ : chloride concentrations $(\mathrm{mMol} / \mathrm{L})$. Group 1: control; group 2: calves experimentally infected with $10^{8} \mathrm{CFU}$ Salmonella Dublin; group 3: calves infected and treated with florfenicol; group 4: calves infected and treated with florfenicol and fluid therapy, before inoculation (0 hour) and 24, 48, 72, 96, 120, 144, and 168 hours after experimental infection.
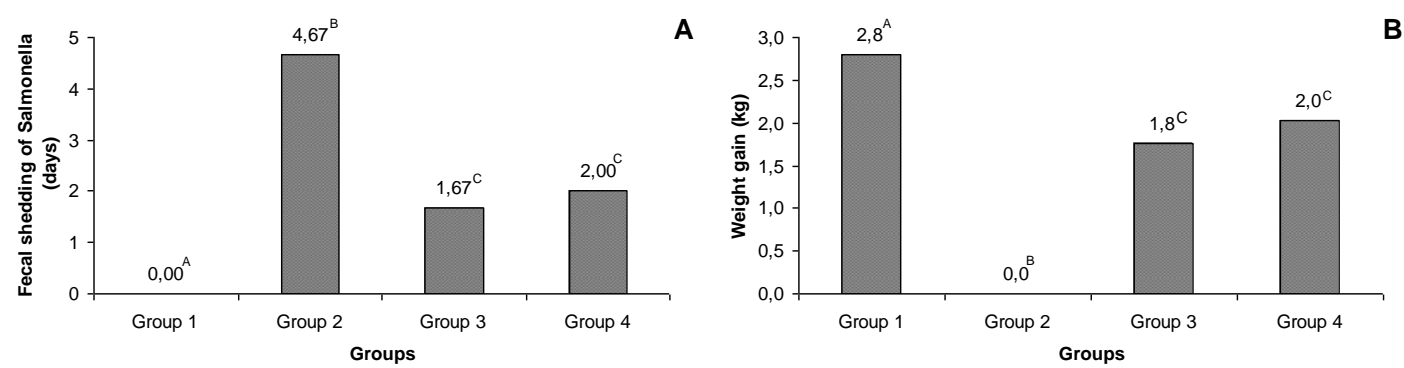

Figure 2. A: representation of the average period of Samonella fecal shedding and $\mathbf{B}$ : body weight gain, during the experimental period of calves from control (group 1), calves experimentally infected with $10^{8} \mathrm{CFU}$ Salmonella Dublin (group 2), calves infected and treated with florfenicol (group 3), and calves infected and treated with florfenicol associated to fluid therapy (group 4). Means followed by the same letters do not differ statistically by Tukey's test $(\mathrm{P}>0.05)$. 
Concerning live weight of the animals seven days after the inoculation, it was observed average gain or loss (kg/animal) of $2.8,-0.1,1.8$, and 2.0 for groups 1, 2, 3, and 4, respectively, indicating that the experimental infection interfered significantly with the weight gain, mainly in animals from group 2 (Figure 2b). According to Rebhun et al. (2000), in calves with salmonellosis, the anorexia usually accompanies the onset of diarrhea, which can be transitory or prolonged. The mortality rates were $83.3 \%$ and $16.7 \%$ in groups 2 and 3 , respectively. In groups 1 and 4 , there were no deaths.

\section{CONCLUSIONS}

The treatment of the experimental salmonellosis in calves with florfenicol was capable to reduce the fecal shedding of Salmonella and to improve the clinical recovery. However, the association of the antibiotic and fluid therapy provided a faster and more efficient control of the hydroelectrolyte imbalance and avoided the occurrence of deaths.

\section{ACKNOWLEDGMENTS}

The authors thank FAPESP for the financial support and scholarships and also Fundação Oswaldo Cruz for providing Salmonella Dublin strain.

\section{REFERENCES}

DIRKSEN, G.; GRÜNDER, H.D.; STÖBER, M. Rosenberger: Exame clínico dos bovinos. 3.ed. Rio de Janeiro: Guanabara Koogan, 1993. 419p.

FECTEAU, M.V.; HOUSE, J.K; KOTARSKI, S.F. et al. Efficacy of ceftiofur treatment of experimental salmonellosis in neonatal calves. Am. J. Vet. Res., v.64, p.918-925, 2003.

GONÇALVES, R.C.; KUCHEMBUCK, M.R.G.; LOPES, R.S. et al. Diarreia em bezerros: estudo clínico e laboratorial. Vet. Zootec., v.3, p.35-44, 1991.

HOUSE, J.K.; SMITH, B.P. Current strategies for managing Salmonella infections in cattle. Vet. Med., v.93, p.756-764, 1998.

LEAL, M.R.L.; MORI, C.S.; ORTOLANI, E.L. Estudo da capacidade alcalinizante de tampões metabolizáveis em bovinos sadios. Arq. Bras. Med. Vet. Zootec., v.59, p.965-970, 2007.
LISBÔA，J.A.N.; BENESI，F.J.; MARUTA, C.A. et al. Tempo de viabilidade de amostras de sangue venoso bovino destinadas ao exame hemogasométrico, quando mantidas sob conservação em água gelada. Cienc. Rural, v.31, p.271-276, 2001.

NAYLOR, J.M. Severity and nature of acidosis in diarrheic calves over and under one week of age. Can. Vet. J., v.50, p.168-173, 1987.

OSBORNE, A.D.; NAZER, A.H; SHIMELD, C. Treatment of experimental calf salmonellosis with amoxicillin. Vet. Rec., v.103, p.233-237, 1978.

PEREIRA, R.N.; ÁVILA, F.A.; FERNANDES, S.A. Estudo do perfil epidemiológico da salmonelose em bezerros e da sensibilidade a antimicrobianos na região de Ribeirão Preto-SP, Brasil. Ars Vet., v.20, p.62-66, 2004.

REBHUN, W.C. Doenças do gado leiteiro. São Paulo: Roca, 2000. 642p.

SANTOS, R.L.; TSOLIS, R.M.; BAÜMLER, A.J. et al. Hematologic and serum biochemical changes in Salmonella ser Typhimuriuminfected calves. Am. J. Vet. Res., v.63, p.11451150, 2002.

SILVA, D.G.; FAGLIARI, J.J.; GARCIA, T.B. Comparação da eficiência dos caldos de enriquecimento seletivo no isolamento de Salmonella Dublin. Arq. Bras. Med. Vet. Zootec., v. 60, p.766-768, 2008a.

SILVA, D.G.; SILVA, P.R.L.; ÁVILA, F.A. et al. Avaliação clínica da infecção experimental de bezerros com Salmonella Dublin. Arq. Bras. Med. Vet. Zootec., v.60, p.121-126, 2008b.

SMITH, B.P.; OLIVER, D.G.; SINGH, P. et al. Detection of Salmonella Dublin mammary gland infection in carrier cows, using an enzyme-linked immunosorbent assay for antibody in milk or serum. Am. J. Vet. Res., v.50, p.1352-1360, 1989.

VELING, J.; BARKEMA, H.W.; SCHANS, I. et al. Herd-level diagnosis for Salmonella enterica subsp. enterica serovar Dublin infection in bovine dairy herds. Prev. Vet. Med., v.53, p.31-42, 2002.

ZAR, J.H. Biostatistical analysis. 4.ed. New Jersey: Prentice Hall, 1999. 663p. 